\title{
PENURUNAN STRES OKSIDATIF SETELAH PEMBERIAN EKSTRAK BIJI JINTAN HITAM (Nigella sativa L.) PADA TIKUS MODEL FIBROSIS HATI
}

\author{
${ }^{1}$ Fathiyah Safithri, ${ }^{2}$ Arina Nuril Fauziyah, ${ }^{1}$ Diah Hermayanti \\ ${ }^{1}$ Fakultas Kedokteran Universitas Muhammadiyah Malang \\ ${ }^{2}$ Pendidikan Dokter Universitas Muhammadiyah Malang
}

Email : fathiyhsafithri@yahoo.com

\begin{abstract}
ABSTRAK
Penyakit fibrosis hati merupakan outcome dari semua jejas hati kronik, dengan manifestasi berupa jaringan parut pada area jejas, hilangnya arsitektur jaringan dan kegagalan fungsi hati. Stres oksidatif berperan penting dalam patogenesis fibrosis hati. Radikal bebas menyebabkan peroksidasi lipid membran sel dan menghasilkan malondialdebid (MDA). Terapi antioksidan diduga memberikan efek menghambat progresifitas kerusakan hati. Biji jintan hitam (Nigella sativa Linn) mengandung antioksidan, antara lain berupa thymoquinon, asam linoleat dan asam oleat. Penelitian ini dilakukan untuk membuktikan efek antioksidan ekstrak biji jintan hitam (Nigella sativa.Linn) terhadap tikus model fibrosis hati, dengan paramater berupa kadar kadar Malondialdehid (MDA) hati. Metode penelitian menggunakan true experimental dengan post test only control group design. Sampel sebanyak 30 tikus yang dikelompokkan menjadi 5 kelompok. Kelompok normal diberi $1 \mathrm{ml} / \mathrm{KgBB}$ corn oil i.p. lalu dilanjutkan pemberian corn oil $1 \mathrm{ml} / \mathrm{KgBB} /$ hari p.o. Satu kelompok kontrol dan 3 kelompok perlakuan diinduksi $\mathrm{CCl}_{4} 1 \mathrm{ml} /$ kgBB i.p 3 kali/minggu selama 8 minggu. Pada minggu ke-9, ketiga kelompok perlakuan diberi ekstrak biji jinten hitam dengan dosis berturut-turut 1,2; 2,4; dan 4,8 g/ kgBB/hari selama 30 hari. Selanjutnya tikus dibedah, diambil jaringan hatinya dan dihitung kadar MDA hati. Pemberian ekstrak N. sativa dapat menurunkan kadar MDA hati $(\mathrm{p}=0,00)$ dan makin besar dosis $\mathrm{N}$ sativa, kadar MDA hati makin rendah $(\mathrm{r}=-0,614)$. Diduga bioaktif ekstrak $N$. sativa meningkatkan aktivitas enzim antioksidan endogen dan menghambat peroksidasi lipid.
\end{abstract}

Kata kunci : ekstrak. N. sativa, MDA hati, tikus, fibrosis hati.

\section{ABSTRACT}

Liver fibrosis is the outcome of all chronic liver injury, with manifestations of scarring in the area of lesion, loss of tissue architecture and failure of liver function. Oxidative stress plays an important role in the pathogenesis of liver fibrosis. Free radicals cause lipid peroxidation of cell membranes and produce malondialdebyde (MDA). Antioxidant therapy inbibit the progression of liver damage. Black cumin seeds (Nigella sativa Linn) contains antioxidants, which include thymoquinon, linoleic acid and oleic acid. This study was conducted to prove the antioxidant effect of $N$. sativa extract in rat model of liver fibrosis, with parameters such as concentration levels of malondialdehyde (MDA) in the liver. The research method using a true experimental with post test only control group design. A sample of 30 rats were divided into 5 groups. Normal group were given $1 \mathrm{ml} / \mathrm{kgBW}$ corn oil i.p. then continued provision of corn oil $1 \mathrm{ml} /$ $\mathrm{kgBW} /$ day p.o. One control group and three treatment groups CCl4 induced $1 \mathrm{ml} / \mathrm{kg}$ i.p 3 times / week for 8 weeks. At 9th week, all of three treatment groups were given N. sativa extract with successive doses of $1.2 ; 2.4$; and $4.8 \mathrm{~g} / \mathrm{kg} /$ day for 4 weeks. Furthermore, rats dissected, taken liver organ and liver $M D A$ calculated. $N$. sativa extract can reduce levels of liver $M D A(p=0.00)$ and the larger the dose of $N$ sativa, the lower liver MDA levels $(r=-0.614)$. Allegedly bioactive extract of $N$. sativa increases endogenous antioxidant enzyme activity and inbibits lipid peroxidation.

Keyword : N. sativa extract, MDA liver, rats, liver fibrosis 


\section{LATAR BELAKANG}

Penyakit fibrosis hati merupakan outcome dari semua jejas hati kronik, dengan manifestasi berupa deposisi protein matrik ekstraseluler yang menghasilkan jaringan parut pada area jejas, hilangnya arsitektur jaringan dan kegagalan fungsi hati (Henderson and Iredale, 2007). Stres oksidatif berperan penting dalam patogenesis fibrosis hati. Radikal bebas merusak komponen seluler, antara lain terjadi peroksidasi lipid membran sel yang menghasilkan metabolit aldehid yang toksik dan reaktif yaitu malondialdehid (MDA) (Singal, 2011). Terdapat hubungan antara kadar MDA dan derajat kerusakan hati, yaitu makin berat kerusakan hati maka kadar MDA makin tinggi (Aksoy, 2003). Fibrosis hati yang berlangsung terus secara progresif akan berakhir sebagai sirosis hati, yang ditandai dengan pergantian progresif sel hati fungsional oleh sel hati non fungsional (Czaja, 2014).

Sirosis hati menjadi penyebab kematian dengan urutan ke-12 di Amerika Serikat, menyebabkan 29.165 kematian di tahun 2007 dengan angka mortalitas 9,7 per 100.000 orang (Starr, 2011), sedangkan di Eropa, sirosis hati menyebabkan 170.000 kematian setiap tahunnya (Blachier, 2013). Faktor-faktor yang menyebabkan terjadinya fibrosis hati antara lain adalah virus hepatitis $\mathrm{C}$, hepatitis $\mathrm{B}$, hepatitis $\mathrm{D}$, alkohol, racun, dan obat. Hepatitis C dan alkohol merupakan penyebab terbanyak (Esparza, 2015). Patomekanisme utama terjadinya fibrosis hati adalah melalui stres oksidatif dan inflamasi. Virus hepatitis-C menyebabkan apoptosis sel hati dan kerusakan mitokondria, sehingga menyebabkan Reactive Oxygen Species (ROS) di hati meningkat (Lach, 2014). Dengan adanya apoptosis dan peningkatan ROS, sel Kuppfer akan teraktivasi. Sel Kupffer yang teraktivasi mengeluarkan mediator Transforming Growth Factor- â (TGF-â ) sebagai agen fibrogenik serta menginduksi peningkatan ROS yang meningkatkan aktivasi sel stelata (Hepatic Stellate Cells /HSCs). Pada kerusakan hati, HSCs akan berproliferasi, membesar dan berubah bentuk menjadi sel yang mirip miofibroblas. Sel HSCs ini memproduksi kolagen dalam jumlah besar, dan selanjutnya berkembang menjadi jaringan fibrosis dan sirosis pada hati (Bataller, 2005). Radikal bebas seperti superoksida dan radikal hidroksil, dapat menyebabkan kerusakan pada komponen seluler antara lain berupa peroksidasi protein, asam nukleat, asam amino bebas, dan lipoprofi

tein. Peroksidasi lipid menyebabkan kerusakan oksidatif lemak tak jenuh ganda (PUFA) pada membran sel dan menghasilkan metabolit aldehida yang toksik dan reaktif, yang disebut sebagai malondialdehyde (MDA). MDA ini sering digunakan sebagai indeks peroksidasi lipid (Aksoy, 2003; Shimizu, 2012).

Penelitian terdahulu membuktikan bahwa antioksidan (vitamin E dan selenium) dapat mengurangi progresifitas fibrosis hati pada tikus model fibrosis hati (Hayani, 2011). Black cumin atau jintan hitam (Nigella sativa L) mengandung beberapa senyawa aktif, antara lain adalah thymoquinone $(30 \%$ $48 \%)$, thymobydro-quinone, dithymoquinone, p-cymene $(7 \%$ $15 \%)$, carvacrol (6\%-12\%), 4-terpineol (2\%-7\%), tanethol (1\%-4) (Ahmad, 2013). Thymoquinone mempunyai efek proteksi sel dari kerusakan yang disebabkan oleh stres oksidatif (Abdelmequid, 2010). Thymoquinone bekerja menghambat stres oksidatif dengan meningkatkan aktivitas enzim Super Oxide Demutase (SOD), enzim glutation dan menghambat reaksi lipid peroksidase (Sogut, 2008). Thymoquinone terbukti secara signifikan menghambat peningkatan kadar MDA kolon pada tikus model Necrotizing enterocolitis (NEC) (Tayman, 2012). Begitu juga pada penelitian yang dilakukan oleh Fouda et al , 2008 membuktikan bahwa Thymoquinone menghambat peningkatan kadar MDA ginjal pada tikus yang diinduksi $\mathrm{HgCl}_{2}$. Selain itu, N. sativa juga mengandung flavonoid dan asam lemak di antaranya linoleic acid dan oleic acid. Linoleic acid dan oleic acid memiliki efek menghambat reaksi lipid peroksidase (Sultan, 2009). Flavonoid bertindak sebagai donor elektron yang merupakan target dari radikal bebas (Kumar, 2007).

Saat ini belum tersedia terapi standar untuk fibrosis hati. Eliminasi faktor penyebab fibrosis hati merupakan tindakan yang efektif untuk menekan progresifitasnya. Pada sirosis yang sudah mengalami komplikasi, transplantasi hati merupakan terapi paling efektif (Arthur, 2002). Terapi antioksidan diduga memberi keuntungan berupa hambatan progesifitas fibrosis menuju sirosis hati. Penelitian sebelumnya telah membuktikan efek proteksi $N$. sativa terhadap hepar. Pada penelitian ini, peneliti meneliti efek kuratif ekstrak $N$. sativa menghambat progresifitas fibrosis hati pada tikus model fibrosis hati yang diinduksi $\mathrm{CCl}_{4}$. Hambatan progresifitas 
ditandai dengan penurunan kadar Malondialdehid (MDA) di hati.

\section{METODE}

\section{Desain Penelitian}

Penelitian yang digunakan adalah true experimental dengan desain posttest only control group design

\section{Pembuatan Ekstrak N. sativa}

Biji Jinten Hitam (Nigella sativa) dicuci dan diblender hingga halus kemudian direndam dalam etanol $90 \%$, digoyang menggunakan shaker selama 20 jam kemudian didiamkan selama 24 jam. Selanjutnya dievaporasi untuk menguapkan etanol sehingga didapatkan ekstrak $N$. sativa yang bebas ethanol.

\section{Pembuatan Latutan $\mathrm{CCl}_{4}$}

$\mathrm{CCl}_{4}$ dilarutkan dalam corn oil di dalam beaker glass dengan perbandingan 1:1, sehingga diperoleh konsentrasi $10 \%$, kemudian mengaduk larutan hingga tercampur rata.

\section{Perlakuan pada Tikus Wistar}

Tikus ditimbang berat badannya kemudian dimasukkan ke dalam kandang yang berisi sekam yang ditutup dengan kawat. Pada tahap persiapan dilakukan pemeliharaan tikus jantan selama 7 hari. Setelah 7 hari tikus dikelompokkan secara random (acak) kemudian diberi label pada masing-masing kandang sesuai perlakuan yaitu normal, kontrol, perlakuan 1, perlakuan 2 dan perlakuan 3. Pada kelompok normal diberi $1 \mathrm{ml} / \mathrm{KgBB}$ corn oil i.p. lalu dilanjutkan pemberian corn oil $1 \mathrm{ml} / \mathrm{KgBB} /$ hari p.o.. Kelompok kontrol, tikus jantan diinjeksi $\mathrm{CCl}_{4}$ i.p 3 kali/minggu selama 8 minggu kemudian dilanjutkan dengan pemberian corn oil selama 4 minggu. Setelah induksi $\mathrm{CCl}_{4}$ selama 8 minggu berakhir, pada ketiga kelompok perlakuan dilanjutkan pemberian ekstrak $N$. sativa p.o setiap hari selama 4 minggu dengan dosis berturu-turut 1,2; 2,4; dan 4,8 g/ kgBB/hari. Setelah perlakuan selesai (minggu ke-12) tikus dimatikan, kemudian dilakukan pembedahan untuk mengambil organ hati dan selanjutnya dilakukan pengukuran kadar MDA hati

\section{Pengukuran Kadar MDA Hati}

Organ hati dengan berat 1 gram dimasukkan ke dalam mortar dingin dan digerus hingga halus. Kemudian $500 \mu \mathrm{L} \mathrm{NaCl} \mathrm{0,9 \%} \mathrm{ditambahkan} \mathrm{dan}$ dilakukan homogenasi. Homogenan diambil dan dipindahkan ke tabung ependrof. Selanjutnya dilakukan sentrifugasi selama 20 menit dan diambil supernatannya. Supernatan sebanyak $100 \mu \mathrm{L}$ dimasukkan ke dalam tabung reaksi, ditambah 550 $\mu \mathrm{L} \mathrm{Na}$ Thio 1\% dan dihomogenkan kembali. Setelah itu disentrifugasi $500 \mathrm{rpm}$ selama 10 menit, dipanaskan dalam waterbath $100^{\circ} \mathrm{C}$ selama 30 menit. Sampel kemudian diukur absorbansinya dengan spektrofotometer pada panjang gelombang maksimum (ë maks $=532 \mathrm{~nm}$ ).

\section{HASIL DAN PEMBAHASAN}

Rerata kadar MDA hati tikus wistar pada masing-masing kelompok tampak pada tabel di bawah ini

\begin{tabular}{|c|c|}
\hline Kelompok & $\begin{array}{c}\text { Rerata kadar } \\
\text { MDA (ng/mg) } \pm \\
\text { Standar deviasi }\end{array}$ \\
\hline Normal & $203.5 \pm 12.19$ \\
\hline Kontrol (Induksi CCl 4 ) & $\begin{array}{cc}244 & \pm \\
10.37 & \end{array}$ \\
\hline $\begin{array}{l}\text { P1 (Induksi } \mathrm{CCl}_{4}+\mathrm{NS} \\
1,2)\end{array}$ & $\begin{array}{rr}220 & \pm \\
10.45 & \end{array}$ \\
\hline $\begin{array}{l}\mathrm{P} 2 \text { (Induksi CCl} \\
2,4)\end{array}$ & $\begin{array}{cc}241 & \pm \\
20.77 & \end{array}$ \\
\hline $\begin{array}{l}\mathrm{P3} \text { (Induksi } \mathrm{CCl}_{4}+\mathrm{NS} \\
4,8)\end{array}$ & $\begin{array}{r}201 \\
15.28\end{array}$ \\
\hline
\end{tabular}

Tabel 1 Efek Pemberian N. sativa terhadap Rerata Kadar MDA Hati

Tabel 1 menunjukkan bahwa rerata kadar MDA hati kelompok kontrol (kelompok tikus yang diinduksi $\mathrm{CCl}_{4}$ ) dan perlakuan pertama (kelompok tikus yang diinduksi $\mathrm{CCl}_{4}$ dan kemudian 
mendapat ekstrak $\mathrm{N}$ sativa $1,2 \mathrm{~g} / \mathrm{kgBB} /$ hari) dan kedua (kelompok tikus yang diinduksi $\mathrm{CCl}_{4}$ dan kemudian mendapat ekstrak $\mathrm{N}$ sativa $2,4 \mathrm{~g} / \mathrm{kg} /$ hari) lebih tinggi daripada kelompok normal. Hal ini menunjukkan bahwa induksi $\mathrm{CCl}_{4}$ menyebabkan peningkatan rerata kadar MDA hati.

Tabel 1 juga menunjukkan bahwa rerata kadar MDA hati kelompok perlakuan lebih rendah dibanding kelompok kontrol. Hal ini menunjukkan bahwa pemberian dosis ekstrak Nigella sativa dengan dosis 1,2 $\mathrm{g} / \mathrm{kgBB} / \mathrm{hr}, 2,4 \mathrm{~g} / \mathrm{kgBB} / \mathrm{hr}, 4,8 \mathrm{~g} /$ $\mathrm{kgBB} / \mathrm{hr}$ dapat menurunkan kadar MDA hati pada tikus yang diinduksi $\mathrm{CCl}_{4}$.

Tabel 1 menunjukkan bahwa di antara ketiga dosis ekstrak $\mathrm{N}$. sativa, kelompok tikus dengan dosis ekstrak $\mathrm{N}$. sativa $4,8 \mathrm{~g} / \mathrm{kgBB} /$ hari yang mempunyai rerata kadar MDA hati yang paling rendah dan mendekati rerata MDA hati kelompok normal. Hal ini menunjukkan bahwa ekstrak N. sativa dosis $4,8 \mathrm{~g} / \mathrm{kgB} \mathrm{B} /$ hari mampu menurunkan rerata kadar MDA hati hingga mencapai rerata MDA hati yang normal. Uji One Way ANOVA menunjukkan bahwa terdapat perbedaan kadar MDA hati yang signifikan antar kelompok penelitian $(\mathrm{p}=000)$. Uji Pearson menunjukkan bahwa terdapat korelasi negatif yang kuat antara dosis ekstrak $\mathrm{N}$. sativa dengan rerata MDA hati $(r=-0,614)$.

\section{PEMBAHASAN}

Pada penelitian ini, pemberian dosis ekstrak N. sativa dengan dosis $1,2 \mathrm{~g} / \mathrm{kgBB} / \mathrm{hr}, 2,4 \mathrm{~g} /$ $\mathrm{kgBB} / \mathrm{hr}, 4,8 \mathrm{~g} / \mathrm{kgBB} / \mathrm{hr}$ dapat menurunkan kadar MDA hati pada tikus model fibrosis hati. Turunnya kadar MDA hati menunjukkan kerusakan hati akibat $\mathrm{CCl}_{4}$ dapat diperbaiki dengan pemberian ekstrak $N$ sativa. Perbaikan kerusakan hati (fibrosis hati) kemungkinan karena $\mathrm{N}$ sativa mengandung beberapa bioaktif ( thymoquinone, asam oleat dan asam linoleat) yang bertindak sebagai antioksidan. Pemberian antioksidan pada fibrosis hati dapat memperlambat progresifitas fibrosis awal menuju sirosis hati (Aksoy, 2003; Ha, 2010; Medina, 2005). Thymoquinone terbukti mempunyai efek protektif pada sel terhadap kerusakan yang disebabkan oleh stres oksidatif (Abdelmequid, 2010; Fouda, 2008). Thymoquinone menghambat stres oksidatif dengan cara meningkatkan aktivitas enzim Super Oxide Demutase (SOD), enzim glutation dan menghambat reaksi lipid peroksidase (Sogut, 2008). Thymoquinone tebukti dapat menurunkan kadar MDA kolon secara signifikan pada tikus dengan induksi model Necrotizing enterocolitis (NEC) (Tayman, 2012).

Asam linoleat dan asam oleat memiliki efek antioksidan yang dapat menghambat reaksi peroksidasi lipid (Sultan, 2009). Flavonoid berfungsi sebagai antioksidan dengan bertindak sebagai donor elektron yang merupakan target dari radikal bebas (Kumar, 2007).

Penurunan MDA berkaitan dengan peningkatan TNF-Related Apoptosis-Induced Ligan (TRAIL), dimana TRAIL ini berfungsi melakukan apoptosis pada sel HSCs, sehingga miofibroblas tidak akan terbentuk dan terjadilah penurunan produksi ECM dan kolagen (Herr, 2012). Penurunan produksi ECM dan kolagen mengawali proses regresi fibrosis. Lambat laun akan diikuti dengan proses supresi aktivitas tissue-inbibitory matrix metalloproteinnase (TIMP) hepatik yang selanjutnya akan diikuti oleh eliminasi miofibroblas hepatik melalui apoptosis, senescence, atau kembali menjadi quiscent. Ekspresi TIMP menurun sehingga terjadi peningkatan aktivitas matrix metalloproteinnase (MMP) dan kolagen akan didegradasi (Bataller and Brenner, 2005; Mallat and Lotersztajn, 2013). Penurunan penumpukan ECM dan kolagen di hati akan memperlambat progresifitas fibrosis awal menjadi sirosis (Moore, 2012).

Hasil penelitian menunjukkan bahwa terdapat korelasi negatif yang kuat antara dosis ekstrak $\mathrm{N}$. sativa dengan rerata MDA hati $(\mathrm{r}=-0,614)$. Makin besar dosis $N$ sativa, maka makin rendah rerata MDA hati. Makin besar dosis $N$ sativa, makin besar pula kandungan bioaktif antioksidannya, sehingga makin besar pula kemampuan memperbaiki kerusakan hati (regresi fibrosis hati) dan memperlambat progresivitas fibrosis awal menuju sirosis (Medina, 2005;Li, 2015).

Oksidatif stres yang disebabkan oleh $\mathrm{CCl}_{4}$ menyebabkan terjadinya peningkatan ROS dan produknya yaitu MDA (Ayala, 2014). Jumlah oksidatif stress dalam tubuh dipengaruhi oleh keseimbangan antara induksi stres oksidatif dengan faktor perbaikan yang terjadi. Perbaikan yang terjadi dilakukan oleh enzim endogen seperti superoxide dismutase (SOD), catalase (CAT) dan glutathione (GSH). Enzim-enzim tersebut terbukti memproteksi sel dari peroksidase lipid (Masubuchi, 2007) . Pada penenlitian ini belum dikaji adakah hubungan 
pemberian ekstrak $N$ sativa dengan aktivitas enzimenzim tersebut.

Hepar mempunyai kemampuan regenerasi sangat tinggi. Regresi fibrosis dapat terjadi secara endogen yang ditunjukkan dengan penurunan ekspresi TIMP-1 dan peningkatan aktivitas MMP13. Menurunnya kadar TIMP-1 menyebabkan terjadinya degradasi jaringan fibrotik oleh MMP13 semakin besar (Henderson and Iridale, 2007)

Berdasarkan hasil yang diperoleh pada penelitian ini dapat disimpulkan bahwa pemberian ekstrak biji Nigella sativa. terbukti dapat menurunkan kadar MDA hati pada tikus model fibrosis hati. Akan tetapi, pada penelitian ini masih belum dapat diketahu mekanisme kerja yang pasti dari ekstrak $N$ sativa sehingga dapat memberikan efek perbaikan terhadap kerusakan hati yang ditandai dengan penurunan kadar MDA.

\section{KESIMPULAN DAN SARAN}

Kesimpulan dari penelitian ini adalah pemberian ekstrak biji jinten hitam (Nigella sativa.Linn) berpengaruh terhadap rerata kadar MDA hati pada tikus model fibrosis hati $(p=0,000$, $\mathrm{r}=-0,614)$ dan dosis ekstrak N.sativa $4,8 \mathrm{~g} /$ $\mathrm{kgBB} /$ hari memberikan efek penurunan rerata MDA hati yang terbesar.

Perlu dilakukan penelitian lebih lanjut untuk mengetahui mekanisme kerja $\mathrm{N}$ sativa dalam memberikan efek perbaikan terhadap kerusakan hati, pengaruh $\mathrm{N}$ sativa terhadap kemampuan regenerasi hati secara endogen, khususnya terhadap enzim-enzim yang bertindak sebagai antioksidan endogen.

\section{DAFTAR PUSTAKA}

Abdelmeguid, E.N., Fakhoury, R., Kamal, M.S., et al. 2010. Effect of Nigella sativa and Thymoquinone on Biochemical and Sebcellular Changes in Pancreatic $\hat{a}$ Cells of Streptozotocin-induced Diabetic Rats. Alexandria University : Faculty of Science, pp. 256-266.

Ahmad, A., Asif, H, Mohd, M., Khan, S.A., Najmi, A.K., et. al. 2013. A Review on Therapentic Potential of Nigella Sativa: A Miracle Herb. Asian Pacific Journal, 3(5), pp. 337352.
Aksoy H, koruk M, Akcay F, 2003, The Relationship Between Serum Malondialdehyde and Ceruloplasmin in Chronic Liver Disease, Turkish Journal of Biochemistry 28 (2) 3234

Arthur, M.J. 2002. Reversibility of liver fibrosis and cirrhosis following treatment for hepatitis Gastroenterology, 122:1525-1528.

Ayala, A., Munoz, F. Mario., Arguelles, S. 2014. Lipid Peroxidation : Production, Metabolism, and Signaling Mechanisms of Malondialdebyde and 4Hydroxy-2-Neonal. University of Seville : Department of Biochemistry and Molecular Biology, Spain, pp. 1-31.

Bataller, R., Brenner, A.D. 2005. Liver Fibrosis. Department of Medicine, Columbia University, New York, USA, pp. 209-218.

Blachier, M., Leleu, H., Radosavljevic, P.M., Valla, C., et al. 2013. The burden of liver disease in Europe: A review of available epidemiological data. Journal of Hepatology, pp. 593-608.

Bray,T., Bettger, W.J.1990. The physiological role of zinc as an antioxidant Free Radical BiolMed; 8(3),pp. 283

Czaja, J.A. 2014. Hepatic inflammation and progressive liver fibrosis in chronic liver disease. World Journal of Gastroenterology, 20(10), pp.2515-2524.

Esparza, M.M., Manzano, T.M., Alcaraz, J.A., et al. 2015. Inflammatory status in buman bepatic cirrhosis. World Journal of Gastroenterology, 21(41), pp.11522-11534.

Fouda AM, Daba MY, Dahab GM, el-Din OAS, 2008, Thymoquinone Ameliorates Renal Oxidative Damage and Proliferative Response Induced by Mercuric Chloride in Rats, Basic \& Clinical Pharmacology \& Toxicology103:109-118

Ha H, Shin H, Feitelson HA, Yu D, 2010, Oxidative stress and antioxidants in hepatic pathogenesis, World Journal Gastroenterology 28; 16(48): 6035-6043

Hayani, A.A. 2011. The Effect of Antioxidant Therapy in Hepatic Fibrosis Induced Experimentally by Bile Duct Ligation in Rats. University of King Abdul Aziz : Department of Anatomy, Saudi Arabia, 10(6), pp. 764-773. 
Henderson NC and Iredale JP, 2007, Liver ûbrosis: cellular mechanisms of progression and resolution, Clinical Science 112, 265-280

Herr, I., Schemmer, P., and Bucher, M. 2012. On TRAIL to therapeutic intervention in Liver Disease

Kumar, D., Lakhanpal, P. 2007. Quercetin: A Versatile Flavonoid. Internet Journal of Medical Update, Vol. 2, No. 2, Jul-Dec 2007

Lach, C.H., Michalak, A. 2014. Oxidative Stress as a Crucial Factor in Liver Disease. World J Gastroenterology, 20(25), pp. 8082-8091.

Li S, Tan H, Wang N, Zhang Z, Lao L, Wong C and Feng Y, 2015, International Journal Molecular Science, 16, 26087-26124

Mallat A and Lotersztajn S, 2013, Cellular Mechanisms of Tissue Fibrosis. 5. Novel insights into liver ûbrosis, American Journal of Physiology Cell 305: C789-C799

Masubuchi,Y., Horie,T. 2007. Toxicology significance of mechanism-based inactivation of cytochrome - P450 enzymes by drugs. Critical reviews in toxicology,vol 37, pp 389-412

Medina J and Moreno-Otero R, 2005, Pathophysiological Basis for Antioxidant Therapy in Chronic Liver Disease, Drugs 65 (17): 2445-2461

Michitaka, K., Nishiguchi, S., Aoyagi, Y., et al. 2009. Etiology of Liver Cirrhosis in Japan : a Nationwide survey. J Gastroenterology, 45(1), pp. 86-94.

Moore, C., and Crocker, S. 2012. An alternate perspective on the roles of TIMPs and MMPs in pathology. The American Journal of Pathology, vol. 180, N0.1, pp.12-15

Sharma, N.K., Ahirwar, D., Jhade. D., et al. 2009. Medicinal and Pharmacological Potential of Nigella sativa: A Review. Ethnobotanical Review, 13 : 946-955

Shimizu, I., Shimamoto, N., Saiki, K., et al. 2012. Lipid Peroxidationi in Hepatic Fibrosis, pp.483492.

Singal AK, Jampana SC, and Weinman SA, 2011, Antioxidants as Therapeutic Agents for Liver Disease, Liver Int.; 31(10): 1432-1448

Sogut, B., Celik, I., Tuluce, Y. 2008. The Effect of Diet Supplemented with Black Cumin Nigella sativa L.) upon Immune Potential and Antioxidant Marker Ensymes and Lipid Peroxidation in Broller Chicks. University of Yuzuncu : Department Biology, 7(10), pp. 1196-1199.
Starr, S.P., Raines, D. 2011. Chirrosis : Diagnosis , Management and Prevention Louisiana State University Health Sciences, New Orleans, Louisiana.

Sultan et al. 2009. Nutritional Profile of Indigenous Cultivar of Black Cumin Seeds and Antioxidant Potential of its Fixed and Essential Oil

Tayman, C., Cekmez, F., Kafa, I.M., Canpolat, F.E., Cetinkaya, M., Uysal, S., et al. 2012. Beneficial effects of Nigella sativa oil on intestinal dam damage in necrotizing enterocolitis. J Invest Surg, 25(5): 286-294. 